\title{
Striving for a low-waste lifestyle
}

$\mathrm{O}$

ur world is overloaded with trash, garbage, and waste. We have major problems with sewage, paper waste, plastic waste, nuclear waste, electronics waste, wasted food, petroleum waste products, runoff of fertilizers and pesticides, and a host of other waste types and materials. As materials researchers, we are complicit in this problem in at least two ways.

First, we, too, are consumers. Some of us always upgrade to the latest cell phone, laptop computer, tablet, television set, sound system, or automobile along with many other usual consumer products. Some of you are probably objecting to my screed at this point, thinking that you recycle and reuse what you can, compost materials when possible, carry reusable tote bags instead of either plastic or paper bags from the stores you frequent, and take other steps to maintain a small ecological footprint. I used to think of myself that way. I knew that I wasn't as environmentally conscious as I needed to be, but I thought that I was exceeding community norms. Then I saw an article about Lauren Singer, who has a goal to produce zero garbage. Her entire collection of waste from four years fits inside one Mason jar. ${ }^{1}$ She is extremely careful about what she buys. She recycles, reuses materials, and composts. And what is left fits within a single 16-ounce jar. Four years of it! I have no clue how she manages this, nor how I could duplicate that result.

Second, for many of us, our research on materials has enabled the development of new products in these same areas of the consumer market or the rapid integration of new materials into products. Some of you may also object to this if you are helping to develop materials that are less toxic, are more biodegradable, or work in some other way to reduce our impact on the environment. However, most of us don't have the habits of Lauren Singer, and don't work on materials that reduce our impact on the environment. On average, Americans generate 4.4 pounds of trash daily per person, equivalent to 254 million tons of trash per year. ${ }^{2}$ This includes 22 billion plastic bottles. In 2012, the amount of trash generated worldwide was 1.3 billion tons. ${ }^{3}$ Obviously, the amount of trash generated in the United States is significantly higher than what is generated by other nations, but think of the total waste. One of my brothers used to refer to me as the incredible bulk. I've weighed about 250 pounds for many years, although more of it was muscle many years ago. The amount of trash generated worldwide each year is more than the weight of 10 billion people of my size.
I recently moved from Hermosa Beach, Calif., to Fayetteville, Ark. In addition to furniture, I had almost 300 boxes of household goods shipped including clothes, dishes, pots and pans, electronics, and books. Lots of books! Most of my belongings were packed in cardboard boxes surrounded by packing paper. Lots of packing paper! Now in Arkansas, as I begin to unpack, I'm having to deal with the solid waste issue. The city allows me two small bins for recyclable materials and one larger bin (9.6 cubic feet) for waste. I place them by the curb on Wednesday evening, and they are picked up on Thursday. I'm having to learn all over again what this city considers recyclable and what is not. The cardboard boxes and the packing paper can be recycled. Other types of paper are not recyclable here. Clear plastic bottles and metal containers can be recycled. Other kinds of plastic cannot be recycled here. If I put materials in the wrong bin, it gets left behind.

The amount of packing paper left over from my move far exceeds what the trash service will pick up during a week. Fortunately, there is a recycling center 1.4 miles from my house. I made a visit already with 10 extra-large garbage bags filled with packing paper. Alas, the paper can be recycled, but the plastic garbage bags cannot be recycled here. So, the garbage bags that I had so carefully filled were torn open, the paper deposited in the appropriate bin, and the garbage bags were taken home to be disposed of as waste. At this rate, I think it will only take me about 20 more special trips to the recycling center to unload all of the recyclable material from my move.

Once plastics were invented, research into plastic materials boomed. We use a tremendous amount of plastic products, and it's causing major environmental problems. Plastics used in many products are not easily or quickly biodegraded. Estimates are that the world has produced more than 9 billion tons of plastic products since its invention, and that almost 7 billion tons have wound up as waste, with less than $10 \%$ of plastic waste winding up in recycling bins. ${ }^{3}$ Much of the plastic waste ends up in our rivers, lakes, and oceans. An area of the Pacific Ocean midway between California and Hawaii is now being referred to as the Great Pacific Garbage Patch, covering about 600,000 square miles. This is an area twice the size of Texas, twice the size of Pakistan, and more than three times the size of Spain. ${ }^{4}$ It contains an estimated 88,000 tons of garbage, much of it plastic. The plastic in our rivers, lakes, and oceans is an ecological disaster, threatening the existence of

many aquatic species. There is a significant amount of research into making plastic bags that biodegrade much more quickly,

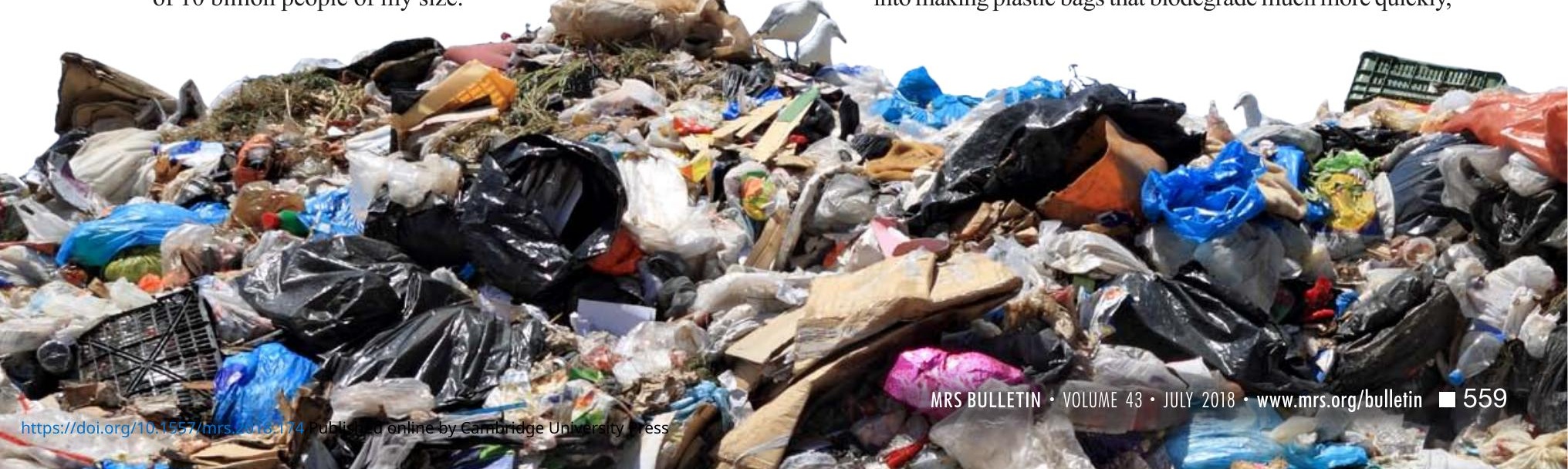


but this has done little to solve our problems. ${ }^{5-8}$ Recently, the EU proposed an initiative to eliminate many plastic products. ${ }^{9}$ Even if that is successful, we will still need robust research efforts toward lessening the environmental impact of plastics.

About half of the trash generated worldwide is organic trash, including wasted food from humans and animals as well as horticultural trash. ${ }^{3}$ Even though I've known about this for some time, it still shocks my tender sensibilities that we waste so much food in parts of the world, particularly considering how many people in other parts go hungry. I confess that I am a party to this as I waste a significant amount of food, whether it's uneaten food from my plate or food from my refrigerator, freezer, or pantry that goes bad before I can eat it. I resolve to do better. There are a number of organizations worldwide that attempt to recover food that would otherwise go to waste and distribute it to the hungry. ${ }^{10}$

Much food waste occurs because of short shelf life. Chilling food has long been known to increase its useful life. Pasteurization is another process that extends the shelf life of foods such as milk. ${ }^{11}$ Materials research in food science has produced other methods to extend shelf life, including the development and use of preservatives, specialized packaging, vacuum packing, packing in gases other than air (e.g., modified atmosphere packaging using nitrogen, carbon dioxide, and limited amounts of oxygen), and incorporating small containers of materials containing oxygen scavengers in the packaging. ${ }^{12}$

In the 1960s, it seemed the landscape teemed with automotive waste. Every community had junkyards containing a seemingly endless collection of rusting hulks of ancient automobiles. Similarly, large fields contained mountains of automobile tires. Sometimes these tires would catch fire and burn for months or years. ${ }^{13}$ Later, many of the junkyards disappeared because the economics of steel production began favoring recovery. Rusting automobiles could be collected, shipped to Japan, and the recovered steel shipped back to the United States cheaper than new steel could be produced. In the years to come, automotive waste will likely include battery materials, unless their economics favors the recovery of rare-earth materials. I suspect some of you are already involved in research efforts to recover valuable materials from batteries ${ }^{14}$ and other automotive waste.

I am a heavy user of consumer electronics. I am working on my fifth Kindle eReader and my fourth iPad. I've purchased several desktop computers and numerous laptops. My use of these and other electronic devices has likely contributed more than my fair share of electronic waste to the world's waste piles. Over the years, I've attempted to rationalize this with my desire to be environmentally responsible by reminding myself that the devices have allowed me to significantly reduce the number of print products (newspapers, magazines, books) that I purchase, and thus significantly reduce my contributions to paper waste. I must admit that I've done no analysis of the tradeoff between the two kinds of waste to assess whether or not this is a fair trade. If I'm completely honest, that may be because I'm so happy with these electronic devices that I don't want to know the answer.
I haven't even touched upon nuclear waste or sewage in this short article. Part of this is because there is not enough room to do justice to all of these topics. Part of it also is because I'm way too squeamish to discuss sewage (yuck!) in the graphic manner that would be required. As for nuclear waste, we know what a terrible problem it poses. My fervent hope is that we, as consumers and materials researchers, will develop approaches to end or at least mitigate these waste problems.

Moving into my new home has exposed me to a new form of trash that I had not previously experienced. My backyard is across the street from a golf course. I find three to four golf balls per week in my yard. It makes me wonder how many golf balls end up as trash each year. Given their structure, they may last longer than plastic products. Soon the world may be awash in lost golf balls. As T.S. Eliot wrote: "And the wind shall say: 'Here were decent Godless people: Their only monument the asphalt road. And a thousand lost golf balls." "15

\section{References}

Steve Moss

1. S. East, "Four Years' Trash, One Jar ... Zero Waste," CNN (July 2, 2016), www.cnn. com/2016/07/04/us/lauren-singer-zero-waste-blogger-plastic/index.html.

2. M. Breyer, "Trash by the Numbers: Startling Statistics about US Garbage," treehugger (July 2, 2016), www.treehugger.com/environmental-policy/trashnumbers-startling-statistics-about-americans-and-their-garbage.html.

3. D. Thompson, "2.6 Trillion Pounds of Garbage: Where Does the World's Trash Go?" Atlantic (June 7, 2012), www.theatlantic.com/business/archive/2012/06/26-trillionpounds-of-garbage-where-does-the-worlds-trash-go/258234.

4. L. Parker, "We Made Plastic. We Depend on It. Now We're Drowning in It," National Geographic (June 2018), www.nationalgeographic.com/magazine/2018/06/plasticplanet-waste-pollution-trash-crisis.

5. J.-P. Kaiser, Macromol. Symp. 165 (1), 115 (2001).

6. F. Pearce, "Biodegradable Plastic Bags Carry More Ecological Harm than Good," Guardian (June 18, 2009), www.theguardian.com/environment/cif-green/2009/ jun/18/greenwash-biodegradeable-plastic-bags.

7. R.E. Farrell, T.J. Adamczyk, D.C. Broe, J.S. Lee, B.L. Briggs, R.A. Gross, S.P. McCarthy, S. Goodwin, "Biodegradable Bags Comparative Performance Study: A Multi-tiered Approach to Evaluating the Compostability of Plastic Materials," ACS Symp. Ser. (February 14, 2001), doi:10.1021/bk-2001-0786.ch021.

8. X. Ren, J. Cleaner Prod. 11 (1), 27 (2003).

9. A. Scott, A. Tullo, Chem Eng. News 96 (23), 4 (2018).

10. L. Furbank, "59 Organizations Fighting Food Loss and Waste," foodtank (2017), https://foodtank.com/news/2016/07/fighting-food-loss-and-waste.

11. "Pasteurization," International Dairy Food Association (2018), www.idfa.org/ news-views/media-kits/milk/pasteurization.

12. R. Clemons, "Extending the Shelf Life of Fresh Food," CHOICE(October 18,2016), www. choice.com.au/food-and-drink/food-warnings-and-safety/food-safety/articles/ extending-the-shelf-life-of-fresh-food.

13. "Tire Fire," Wikipedia (last edited May 30, 2018), https://en.wikipedia.org/wiki/ Tire_fire.

14. M. Bohlsen, "A Look at the Lithium-Ion Battery Recycling Industry and Companies," Seeking Alpha (January 23, 2018), https://seekingalpha.com/article/4139266look-lithium-ion-battery-recycling-industry-companies.

15. T.S. Eliot, "Choruses from The Rock," Collected Poems 1909-1962 p. 145 (1963)

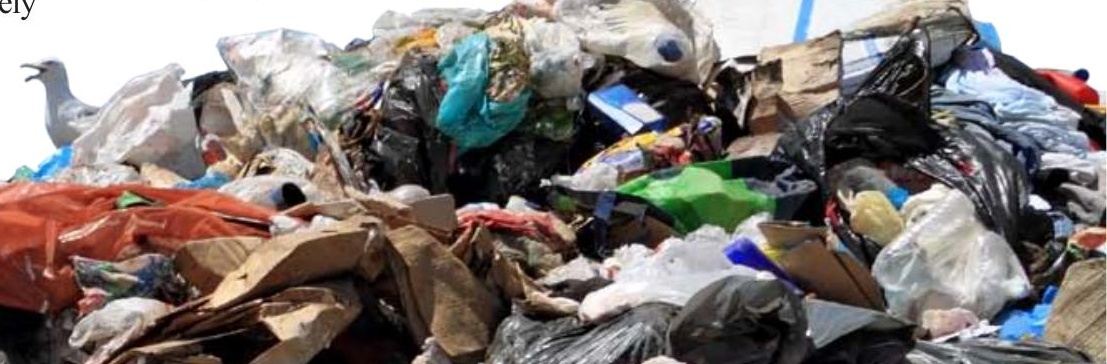

